\title{
Allergen-induced increase in nonallergic airway responsiveness: A citation classic revisited
}

\author{
Donald W Cockcroft MD FRCPC \\ Division of Respiratory Medicine, Department of Medicine, \\ Royal University Hospital, Saskatoon, Saskatchewan
}

DW Cockcroft. Allergen-induced increase in nonallergic airway responsiveness: A citation classic revisited. Can Respir J 2000;7(2):182-187.

BACKGROUND:The present paper revisits the 1977 paper by DW Cockcroft, RE Ruffin, the late J Dolovich and FE Hargreave entitled "Allergen-induced increase in nonallergic bronchial reactivity" (Clin Allergy 1977;7:503-13) that became a citation classic. Although clinical types of asthma were recognized at the time, there was a poor understanding regarding the role of allergic reactions in causing increases in airway hyperresponsiveness. The objective was to study formally Dr Altounyan's observation that patients with asthma showed increases in airway responsiveness at the times of natural allergen exposure during pollen season. Thirteen atopic patients with asthma were studied over two days, following inhalation of diluent (control) and following doubling amounts of an allergen solution at 10 -min intervals until forced expiration volume in $1 \mathrm{~s}$ fell by $20 \%$. Methacholine and histamine challenges were performed before, at $8 \mathrm{~h}$, at
$32 \mathrm{~h}$ and seven days following the inhalations. A significant reduction (reduction of at least one doubling concentration) in the provocative concentration that causes a $20 \%$ fall in forced expiration volume in $1 \mathrm{~s}$ occurred in seven of 13 patients, and more often in subjects with a late bronchoconstrictor response to allergen challenge.

IMPORTANCE: The study showed that large changes in airway responsiveness could occur in patients with asthma and suggested that allergens could cause, rather than trigger, asthma. The study also led to the concept of asthma inducers and inciters - inducers causing airway inflammation and inciters provoking bronchospasm. The results led to a series of observations that have now implicated immunoglobulin E-mediated airway inflammation as perhaps the most important cause of airway hyperresponsiveness in asthma.

Key Words: Airway hyperresponsiveness; Allergen; Asthma; immunoglobulin $E$ 


\section{Augmentation de la réactivité bronchique non allergique induite par des allergènes : un clas- sique en matière de citation revisité}

HISTORIQUE : Le présent article revisite l'article de 1977 de DW Cockcroft, RE Ruffin, du défunt J Dolovich et de FE Hargreave intitulé « Allergen-induced increase in non allergic bronchial reactivity » (Clin Allergy 1977;7 :503-13) devenu un classique en matière de citation. Bien qu'à cette époque, on avait identifié des types cliniques d'asthme, on ne comprenait pas vraiment quel était le rôle des réactions allergiques dans l'augmentation de l'hyperréactivité bronchique. L'objectif était d'étudier en bonne et due forme l'observation du docteur Altounyan selon laquelle des patients asthmatiques montraient des augmentations de la réactivité bronchique lorsqu'ils étaient naturellement exposés à des allergènes pendant la saison des pollens. Treize patients atopiques atteints d'asthme ont été étudiés pendant deux jours, après avoir inhalé un diluant (témoin) et après le doublement des quantités d'une solution contenant des allergènes à des intervalles de 10 minutes jusqu'à ce que le volume expiratoire maximum/seconde (VEMS) ait chuté de $20 \%$. Des tests de provocation à la métacholine et à l'histamine ont été pratiqués avant l'inhalation d'allergènes ainsi que 8 heures, 32 heures et 7 jours après les inhalations. Une réduction significative (réduction d'au moins un doublement de concentration) dans la concentration utilisée pour la provocation qui entraîne une chute de 20 \% du VEMS est survenue chez sept des 13 patients, et plus souvent chez des sujets faisant l'objet d'une réponse bronchoconstrictive tardive au test de provocation avec un allergène.

IMPORTANCE : L'étude a démontré que des changements importants dans la réactivité bronchique pouvaient survenir chez des patients asthmatiques et laissait à penser que des allergènes pouvaient causer plutôt que déclencher l'asthme. L'étude a aussi conduit aux concepts de facteurs déclenchants et précipitants de l'asthme - les facteurs déclenchants causant l'inflammation des voies aériennes et les facteurs précipitants provoquant le bronchospasme. Les résultats ont donné lieu à une série d'observations qui ont maintenant impliqué une inflammation des voies aériennes médiée par les immunoglobulines E comme peut-être la cause la plus importante de l'hyperréactivité bronchique dans l'asthme.
$\mathrm{I}^{\mathrm{n}}$ 1977, it was shown under controlled circumstances in the laboratory that a brief allergen exposure could cause rapid and substantial changes in airway responsiveness to histamine and methacholine, and that these changes often persisted for several days and appeared to be clinically relevant (1). This was a fundamental observation in altering our views regarding both the mechanisms and the importance of immunoglobulin E ( $\mathrm{IgE}$ )-mediated allergen reactions in the pathogenesis of asthma. For these reasons, I regard this as a pivotal observation. In 1993, having received more than 500 citations in the scientific literature, this paper was named a 'citation classic' (2). This paper reviews some of the history regarding this investigation and attempts to emphasize the importance of these observations.

\section{PROLOGUE}

This study was carried out during my two-year Medical Research Council (MRC) of Canada Fellowship that I was extremely fortunate to have spent working with Dr Freddy Hargreave. My position as an MRC Fellow in Dr Hargreave's laboratory at the Regional Chest and Allergy Unit, St Joseph's Hospital, McMaster University, Hamilton, came about serendipitously and involved a string of false assumptions. I had assumed that a year or two of research was mandatory for specialization in respiratory disease (not entirely true). Furthermore, based on early exposure to bench research, I felt that I was unlikely to enjoy clinical research (completely false). I chose Hamilton over Winnipeg in part because I could not imagine enjoying living on the Canadian Prairies even for a year or two; once again, I was obviously in error. In any event, my exploratory letter of interest in 1974 was sent to Dr Moran Campbell who passed it on to Dr Norman Jones, who was then the Division Head. Dr Jones, seeing that my training included a year of allergy and clinical immunology, passed the letter on to Dr Hargreave who was establishing a presence in clinical research in asthma, particularly in the field of bronchoprovocation. Dr Hargreave hired me as his first fellow.

The two years in Hamilton changed my views regarding enjoyment of (clinical) research and thereby shaped my future career. I am forever grateful to Freddy and his close colleague, the late Dr Jerry Dolovich, for both the education and the enjoyment of those two years and the subsequent 23 years.

This investigation was carried out in the early part of 1977 during the winter. Dr Dick Ruffin, a visiting BoehringerIngelheim Research Fellow from Australia, and myself, performed these challenges, often on weekends. Using two challenge systems and two spirometers, Dick and I performed as many as four allergen challenges/day.

\section{INVESTIGATION}

Background: In revisiting this investigation, I believe the background and introduction of this paper should focus more on the poorly understood importance of allergens in the pathogenesis of asthma at that time. Allergy as a cause of disease was a relatively recently recognized syndrome. In 1907, hay fever (including asthma), although felt to be increasing in prevalence, was regarded as a "comparatively rare disease" (3). Toxins contained in pollen were erroneously thought to be the cause of the disease; however, this concept led to the early use of allergen injection therapy (3). The term allergy was not coined until 1906 (4). In 1921, the pollen toxin theory was disproven by the observation of passive transfer of pollen sensitivity (5). Shortly thereafter in 1923, the terms 'atopy' and 'reagin' (later termed reaginic antibody) were introduced (6), and, in 1927, the concept of intrinsic and extrinsic (atopic allergic) asthma was introduced (7). It was not until 1967 that reaginic antibody was identified as IgE, a new class of human serum antibody (8). The remarkable increase in the prevalence of atopic disease over the past cen- 


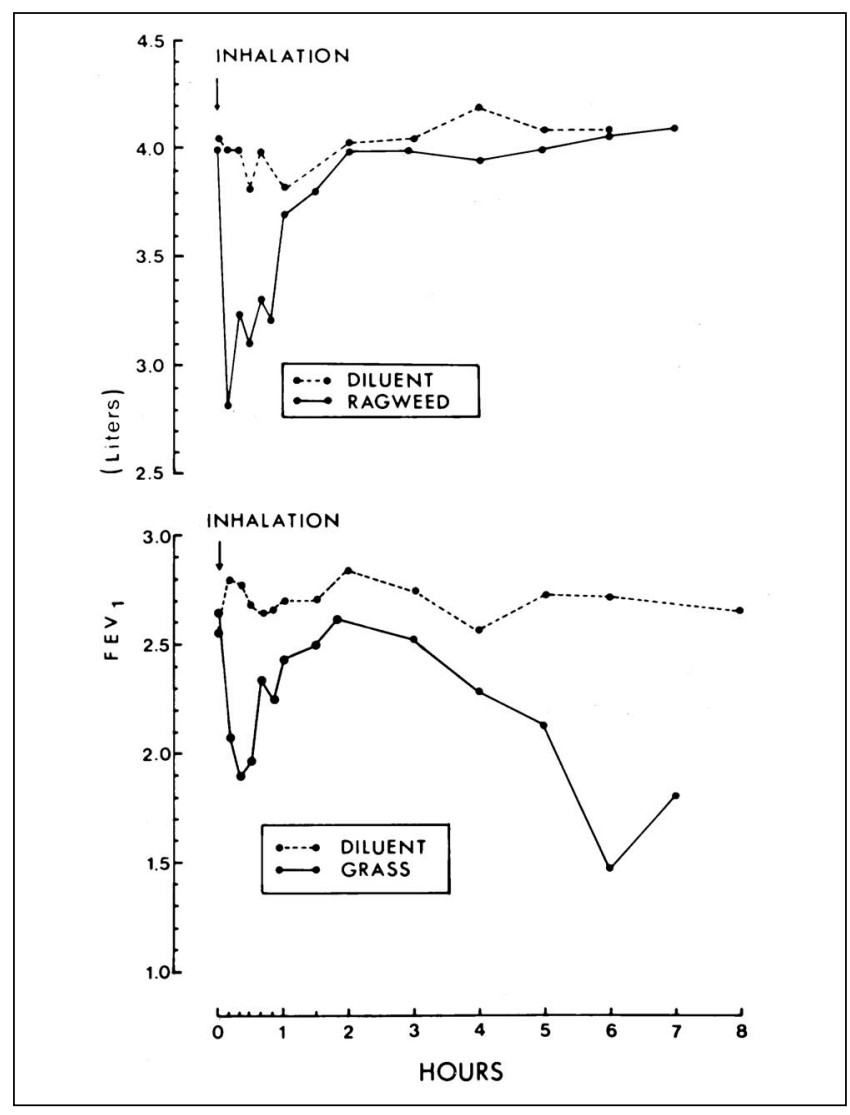

Figure 1) Diluent controlled allergen challenges with spirometry monitored for 7 or $8 \mathrm{~h}$. Forced expiration volume in $1 \mathrm{~s}\left(F E V_{1}\right)$ (litres) is on the vertical axis and time after allergen challenge (hours) on the horizontal axis. The top panel shows a subject with an isolated early asthmatic response (EAR) following a ragweed pollen extract inhalation; there is no late asthmatic response (LAR). The bottom panel shows a dual asthmatic response with an EAR response followed by spontaneous recovery and development of a LAR maximal at $6 \mathrm{~h}$ after allergen challenge. Modified and reproduced from reference 25 with permission

tury or two is undoubtedly in large part because of increased recognition and understanding of the condition. At the time of the 1977 study, extrinsic asthma was recognized as a subtype of asthma, suggesting that atopy and asthma occurred together more often than by chance. However, there was little or no literature suggesting IgE-mediated allergy was a cause of asthma, nor any hint of mechanisms regarding the link between IgE-mediated reactions and the physiological abnormalities, including airway hyperresponsiveness, seen in asthma. In fact, at that time, there was a wide rift between specialists in allergy and respiratory medicine regarding the disease called asthma.

By the mid-1970s, measurement airway responsiveness to histamine or methacholine was becoming recognized as a valuable tool in studying the airways of patients with asthma (9). As had been hypothesized (10), the degrees of airway hyperresponsiveness had recently been documented as an important determinant of the airway response to allergen (11). In the mid-1970s, significant short term variability in airway hyperresponsiveness had not been generally appreci-

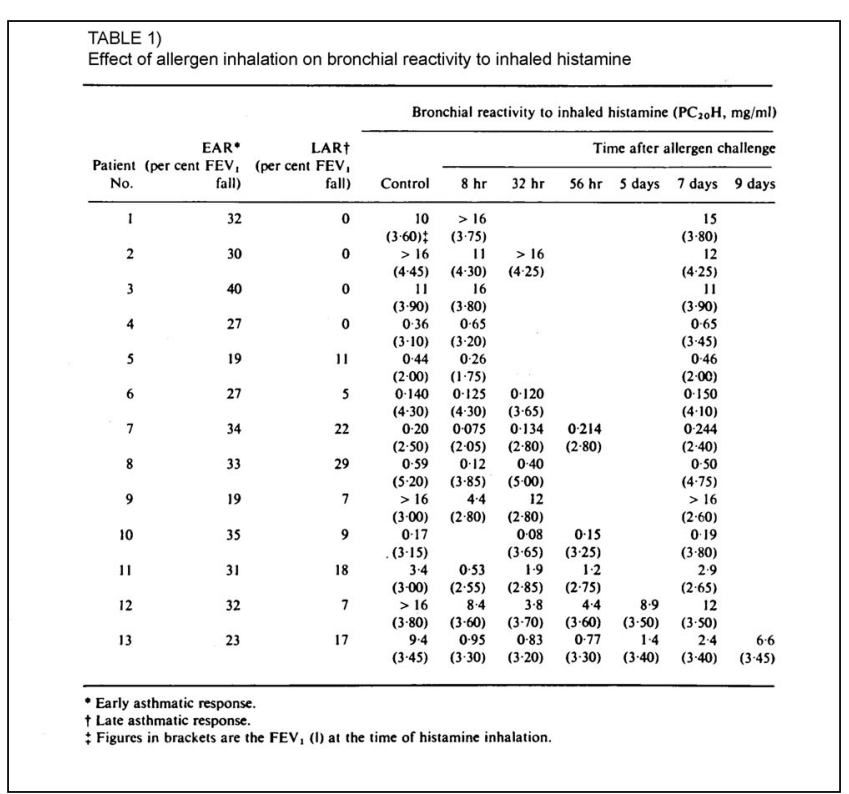

Figure 2) Early asthmatic response (EAR), late asthmatic response $(L A R)$ and histamine provocative concentration that causes a $20 \%$ fall in forced expiration volume in $1 \mathrm{~s}\left(F E V_{1}\right)\left(P C_{20}\right)$ results in the 13 subjects. Data reproduced from reference 1 with permission

ated. It was Roger Altounyan's astute observation in 1964 on the stability of histamine airway responsiveness that prompted the 1977 investigation. Dr Altounyan noted that airway responsiveness to histamine was remarkably constant throughout the year but “... patients with seasonal asthma were the exception, as they showed a marked increase in sensitivity coincident with the onset of the asthma season ..." (12). This was further commented on in 1970 (13). Dr Altounyan's observations of seasonal increases in airway responsiveness were novel, largely unappreciated and prompted the study.

\section{METHODS}

The investigation was relatively simple. The $7 \mathrm{~h}$ diluentcontrolled asthma challenge methodology had been published previously (14). On a control day, diluent is inhaled by tidal breathing at 10-min intervals on three occasions and forced expiration volume in $1 \mathrm{~s}\left(\mathrm{FEV}_{1}\right)$ is measured before, 10 mins after each inhalation and after the last inhalation every 10 mins for the first hour, every 30 mins for the second hour and hourly for the next $5 \mathrm{~h}$. The diluent inhalation provides a control for any early response-related irritant effect of diluent inhalation or repeated spirometry and for any late fluctuations in $\mathrm{FEV}_{1}$. On the second day, doubling amounts of allergen are inhaled at 10 -min intervals and FEV 1 is repeated in the same fashion. The challenge is stopped when there is a $20 \%$ fall in $\mathrm{FEV}_{1}$ and $\mathrm{FEV}_{1}$ is monitored for $7 \mathrm{~h}$ thereafter. Examples of diluent-controlled isolated early asthmatic response (EAR) and diluent-controlled EAR followed by a late asthmatic response (LAR) are shown in Figure 1.

Likewise, the histamine and methacholine challenge methodology, also a citation classic having now been cited over 
1400 times, had previously been published from Dr Hargreave's laboratory (9).

We combined these methods and examined the methacholine provocative concentration that causes a $20 \%$ fall in $\mathrm{FEV}_{1}$ $\left(\mathrm{PC}_{20}\right)$ and histamine $\mathrm{PC}_{20}$ in that order, between 7 and $9 \mathrm{~h}$ after the diluent challenge and again at the same times after the allergen challenge in 13 atopic patients undergoing allergen challenge. Following the allergen challenge, methacholine and histamine challenges were repeated the next afternoon (approximately $33 \mathrm{~h}$ after the allergen exposure) and in selected individuals, measurements were repeated intermittently for several days thereafter; all patients had repeat measurements of airway responsiveness at seven days.

\section{RESULTS}

The results were summarized in Table 2 of the 1977 paper, which is reproduced here as Figure 2. Four of the patients had an isolated EAR with no LAR (less than $5 \% \mathrm{FEV}_{1}$ fall). Four patients had an EAR followed by a definite (greater than $15 \%$ $\mathrm{FEV}_{1}$ fall) LAR. Five subjects had an EAR followed by an equivocal LAR ( $5 \%$ to $15 \% \mathrm{FEV}_{1}$ fall). Based on the reproducibility of the histamine and methacholine $\mathrm{PC}_{20}$ s, we felt that a fall in $\mathrm{PC}_{20}$ of $-50 \%$ was significant; ie, -1 doubling concentration reduction. Seven of the 13 subjects showed a significant increase in airway responsiveness to histamine and six of seven to methacholine. This occurred in all four subjects with a definite LAR and three of five subjects with the equivocal LAR (Figure 2).

Results for a single patient are shown in Figure 3 (modified from Figure 2 in the original paper). This woman was asymptomatic on no asthma medications at the time of the study in the winter. Her histamine $\mathrm{PC}_{20}$ was above $8 \mathrm{mg} / \mathrm{mL}$, which was regarded as normal at that time. A $23 \%$ EAR was followed by a $17 \%$ LAR; both of these were spontaneously reversible. The histamine $\mathrm{PC}_{20}$ fell to less than $1 \mathrm{mg} / \mathrm{mL}$ (moderately hyperresponsive) and remained reduced until spontaneously returning to within one doubling concentration at day 9. The increased airway responsiveness was associated with the recurrence of asthma symptoms provoked by nonallergic stimuli such as smoke, cold air and exercise; the symtoms resolved with resolution of the airway responsiveness.

\section{WHAT WAS LEARNED}

The observation, in controlled circumstances, of definite and large changes of airway responsiveness after allergen challenge resulted in a series of related new or relatively new (previously unappreciated) concepts.

- By inducing airway responsiveness and associated symptoms, it was possible to argue that allergens could be regarded as a cause of the underlying asthma diathesis as opposed to just triggers of bronchospasms and symptoms in patients with asthma.

- The recognition that allergens as well are low molecular weight sensitizing chemicals (15) and viral respiratory tract infections (16) could lead to

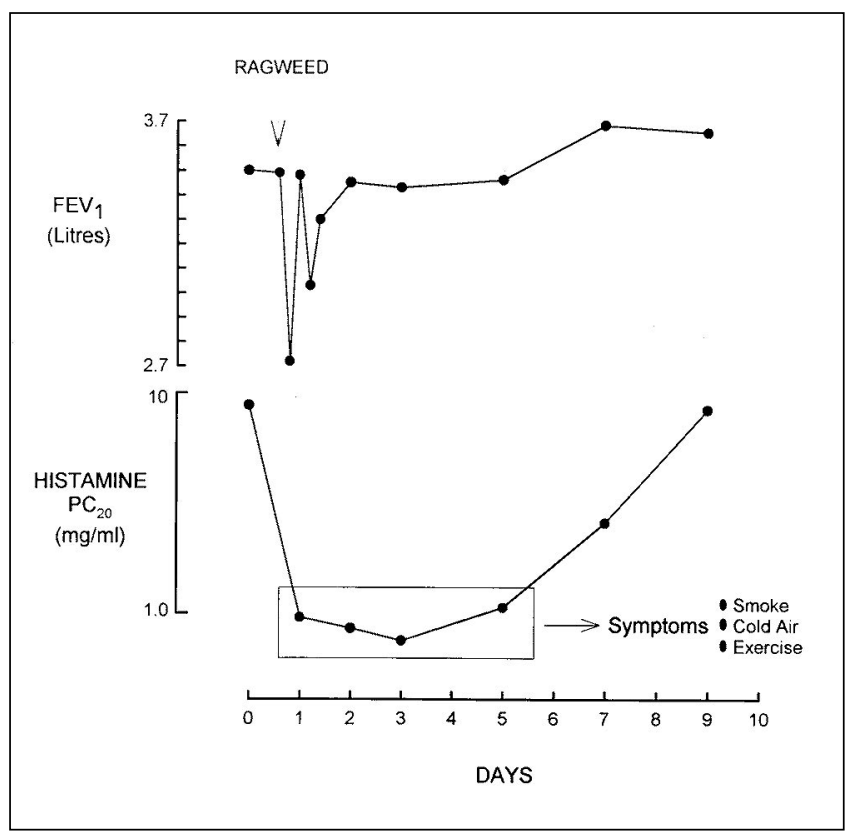

Figure 3) Allergen-induced increase in airway responsiveness. The vertical axis on the top panel is forced expiration volume in $1 \mathrm{~s}$ $\left(F E V_{1}\right)$ in litres and the bottom panel is the histamine provocative concentration that causes a $20 \%$ fall in $F E V_{1}\left(P_{20}\right)$ (log scale) in $\mathrm{mg} / \mathrm{mL}$ graphed against days on the horizontal axis. This patient (subject 13, figure 2) had a spontaneously reversible dual asthmatic response after a brief inhalation of ragweed pollen. $P C_{20}$ fell by greater than 10-fold from borderline to moderately hyperresponsive; this was associated with symptoms on exposure to nonallergic triggers such as smoke, cold air and exercise. Modified and reproduced from reference 25 with permission

increases in airway responsiveness led to an important differentiation of asthma stimuli. It was suggested that asthma stimuli that increased airway responsiveness should be referred to as inducers whereas those that merely triggered bronchospasm and symptoms in people with asthma should be called inciters or triggers (17).

- Our hypothesis as expressed in the discussion of the paper was that the inducers likely shared the common property of inducing inflammation. The observation that airway responsiveness to histamine and methacholine was variable to this extent was not widely recognized previously.

- The possibility that serial determinations of $\mathrm{PC}_{20}$ might be a surrogate for the demonstration of either increased or worsened airway inflammation follows logically but was not suggested in our original discussion.

\section{WHAT WE HAVE LEARNED SINCE}

Our observation of large and clinically relevant allergeninduced increases in airway responsiveness was a pivotal observation. Although we did not directly address airway inflammation, these observations were an early piece in the puzzle that opened (or reopened) our eyes to the importance 


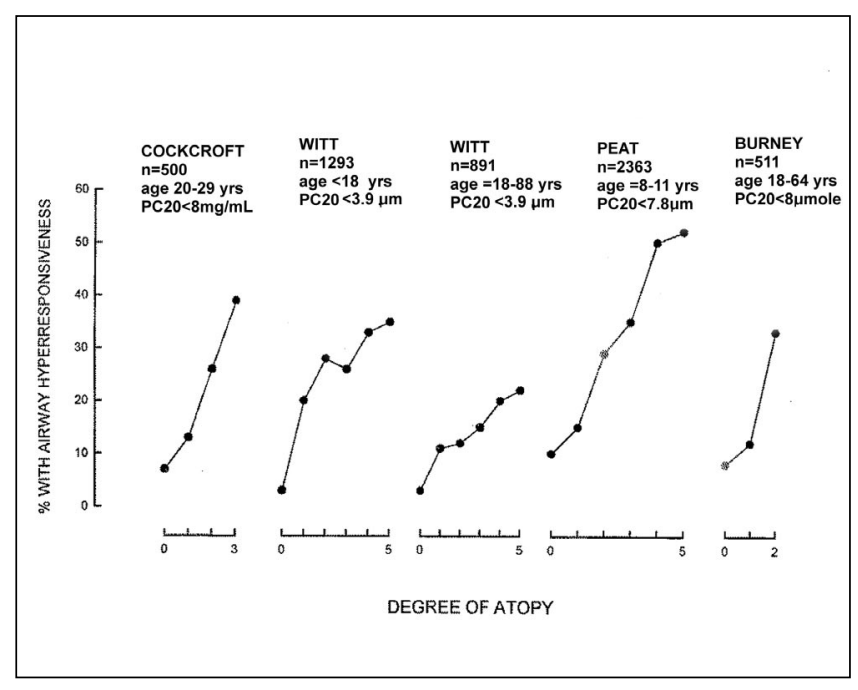

Figure 4) The relationship between airway responsiveness and atopy in five populations in four published studies. The proportion of the population with airway responsiveness (histamine) is on the vertical axis and the severity of atopy (various scales front zero to two, zero to three and zero to five) on the horizontal axis. In all five populations, there is a highly significant increase in the prevalence of airway responsiveness as the severity of atopy increases. The most highly atopic individuals have a prevalence of airway hyperresponsiveness between $30 \%$ and more than $50 \%$ in most of the studies. $P C_{20}$ Provocative concentration that causes a $20 \%$ fall in $F E V_{1}$. Reproduced and adapted with permission from reference 26

of airway inflammation in the pathogenesis of asthma. Some of the cardinal investigations that followed our original study are outlined below. These include further characterization of allergen-induced increases in airway responsiveness, the link with allergen-induced airway inflammation and the importance of IgE-mediated allergen disease in the pathogenesis of clinical asthma in populations.

- A follow-up study by Dr Andre Cartier in Freddy Hargreave's laboratory showed that allergen-induced increased airway responsiveness was closely related to the late response in people with asthma and, furthermore, it was not possible to attribute the increased airway responsiveness to alterations in baseline airway calibre (18).

- Dr Louis-Philippe Boulet's follow-up study in Dr Freddy Hargreave's laboratory confirmed the clinical relevance of these laboratory findings by showing marked seasonal increases in airway responsiveness to methacholine that occurred in the same subjects who had shown the phenomenon in the laboratory (19).

- Dr Jan de Monchy performed the first study showing that allergen-induced increase in bronchoalveolar lavage (BAL) eosinophilia occurred during and following the allergen-induced late response in people with asthma but not in other circumstances, including the isolated EAR (20).

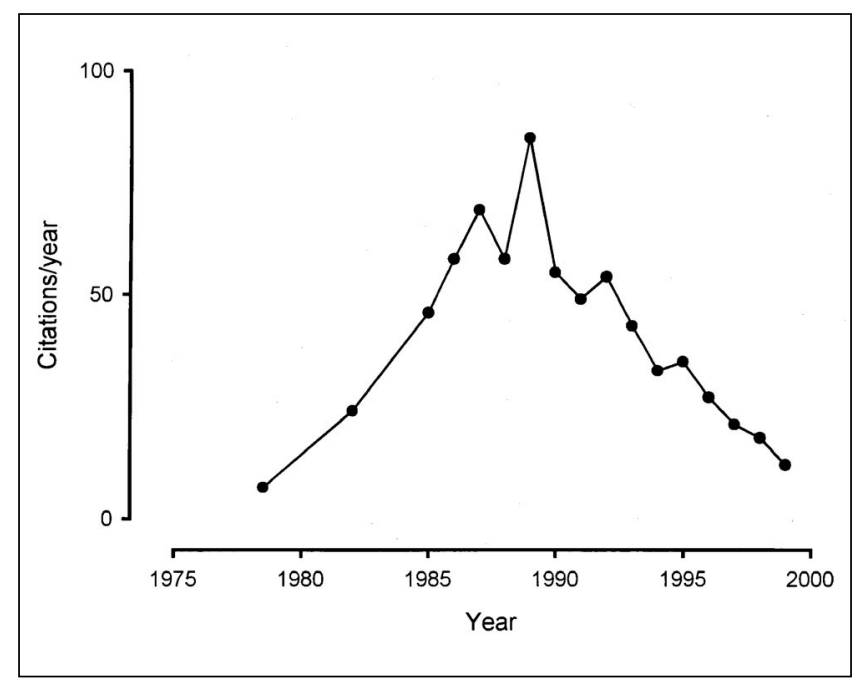

Figure 5) Citations/year on the vertical axis versus calendar year (horizontal axis) for the allergen-induced increase in airway responsiveness paper. The 1977 to 1984 average citations per year based on two and five-year totals; 1999 extrapolated from the first six months of the year. Data extracted from the Science Citation Index, Institute for Scientific Information, Philadelphia, 1978 to 1999

- Dr John Kirby, working in Freddy Hargreave's laboratory, performed the first study documenting a correlation between increased airway responsiveness to methacholine and increased BAL inflammatory cells, particularly eosinophils and metachromatic cells (basophils and/or mast cells) (21).

- We made the initial observation that the prevalence of airway hyperresponsiveness in a random population correlated with the magnitude of atopy (22). This has since been confirmed in numerous studies. The results of four of these investigations are shown in Figure 4.

- Dr Ben Burrows confirmed the relationship between atopy and asthma (history) in a random population but observed an even better correlation with the serum IgE and asthma (23).

The cardinal investigations outlined above provide a plausible link between allergen-induced airway inflammation and allergen-induced airway hyperresponsiveness. The population studies linking asthma and airway hyperresponsiveness to skin test atopy and serum IgE provide solid evidence that IgE-mediated allergic events are an important cause of asthma. In fact, it appears likely that allergen exposure is the most common cause of airway hyperresponsiveness in asthma. Subsequent recent investigations have included studies into the cellular and molecular pathogenesis of events linking IgE-mediated reactions and airway inflammation. In addition, the importance of allergen exposure, particularly early in life (24), has led to important theoretical strategies for the primary prevention of asthma. 


\section{EPILOGUE}

A rather simple investigation in 1977, based on the clinical observations of Roger Altounyan, confirmed significant and moderately long lasting allergen-induced increase in the airway responsiveness to both histamine and methacholine. This was a pivotal observation in two related areas; it provided first, one step towards the recognition of asthma as primarily an inflammatory disease and, second, it was an early observation into the importance of IgE-mediated allergic reactions as a cause of asthma. These important observations have been cited almost 800 times (Figure 5).

ACKNOWLEDGEMENTS: I thank Jacquie Bramley for preparation of the manuscript. Special thanks to Dr Freddy Hargreave and Dr Jerry Dolovich for an instructive and collegial two years in Hamilton. I also thank my coresearch fellow, Dr Dick Ruffin.

\section{REFERENCES}

1. Cockcroft DW, Ruffin RE, Dolovich J, Hargreave FE. Allergen induced increase in nonallergic bronchial reactivity. Clin Allergy 1977; 7:503-13.

2. Cockcroft DW. The secret of allergen-induced asthma. Citation classic commentary. Current Contents (Clinical Medicine) 1993;21:8.

3. Dunbar WP. Hay fever. In: Osler W, ed. Modern Medicine, Vol.III: Infectious Diseases and Diseases of the Respiratory Tract. Philadelphia: Lea Brothers \& Company, 1907:605-21

4. Simons FER, ed. Ancestors of Allergy. New York: Global Medical Communications Ltd, 1994:110-2.

5. Prausnitz C, Küstner H. Studien über die ueberempfindlichkeit. Centralblatt für Bakteriologie, Parasitenkunde und Infektionskrankeiten 1921;86:160-9.

6. Coca, AF. Excerpts From Classics in Allergy, 2nd ed. In: Cohen SG, Samter Max, eds. Carlsbad: Symposia Foundation, 1992;94-5.

7. Rackemann FM. Studies in asthma I. A clinical survey of 1074 patients with asthma followed for two years. J Lab Clin Med 1927;12:1185-97.

8. Ishizaka K, Ishizaka T. Identification of E-antibodies as a carrier of reaginic activity. J Immunol 1967;99:1187-98.

9. Cockcroft DW, Killian DN, Mellon JJA, Hargreave FE. Bronchial reactivity to inhaled histamine: a method and clinical survey. Clin Allergy 1977;7:235-43.

10. Tiffencau R. Hypersensibilité cholinergo-histaminique pulmonaire de l'asthmatique. Allergologica 1958;12(Suppl V):187-221.

11. Killian D, Cockcroft DW, Hargreave FE, Dolovich J. Factors in allergen-induced asthma: relevance of the intensity of the airways allergic reaction and non-specific bronchial reactivity. Clin Allergy 1976;6:219-25.

12. Altounyan REC. Variation of drug action on airway obstruction in man. Thorax 1964;19:406-15.

13. Altounyan REC. Changes in histamine and atropine responsiveness as a guide to diagnosis and evaluation of therapy in obstructive airways disease. In: Pepys J, Franklands AW, eds. Disodium Cromoglycate in Allergic Airways Disease. London: Butterworths, 1970:47-53.

14. Robertson DG, Kerigan AT, Hargreave FE, Chalmers R, Dolovich J. Late asthmatic responses induced by ragweed pollen allergen. J Allergy Clin Immunol 1974;54:244-54.

15. Vallières M, Cockcroft DW, Taylor DM, Dolovich J, Hargreave FE. Dimethyl ethanolainine-induced asthma. Am Rev Respir Dis 1977; 115:867-71.

16. Empey DW, Laitinen LA, Jacobs L, Gold WM, Nadel JA. Mechanisms of bronchial hyperreactivity in normal subjects after upper airway respiratory tract infection. Am Rev Respir Dis 1976;113:131-9.

17. Dolovich J, Hargreave FE. The asthma syndrome: inciters, inducers, and host characteristics. Thorax 1981;36:641-4

18. Cartier A, Thomson NC, Frith PA, Roberts R, Hargreave FE. Allergeninduced increase in bronchial responsiveness to histamine: relationship to the late asthmatic response and change in airway caliber. J Allergy Clin Immunol 1982;70:170-7.

19. Boulet L-P, Cartier A, Thomson NC, Roberts RS, Dolovich J, Hargreave FE. Asthma and increases in nonallergic bronchial responsiveness from seasonal pollen exposure. J Allergy Clin Immunol 1983;71:399-406.

20. de Monchy JGR, Kauffman HF, Venge P, et al. Bronchoalveolar eosinophilia during allergen-induced late asthmatic reactions. Am Rev Respir Dis 1985;131:373-6.

21. Kirby JG, Hargreave FE, Gleich GJ, O’Byrne PM. Bronchoalveolar cell profiles of asthmatic and non-asthmatic subjects. Am Rev Respr Dis 1987; $136: 379-83$.

22. Cockcroft DW, Murdock KY, Berscheid BA. Relationship between atopy and bronchial responsiveness to histamine in a random Population. Ann Allergy 1984;53:26-9.

23. Burrows B, Martinez FD, Halonen M, Barbee RA, Cline MG. Association of asthma with serum IgE levels and skin-test reactivity to allergens. N Engl J Med 89;320:271-7.

24. Peat JK, Saloine CM. Woolcock AJ. Longitudinal changes in atopy during a 4-year period: relation to bronchial hyperresponsiveness and respiratory symptoms in a population sample of Australian school children. J Allergy Clin Immunol 1990;85:65-74.

25. Cockcroft DW. Mechanism of perennial allergic asthma. Lancet 1983;ii:253-6.

26. Cockcroft DW, Hargreave FE. Relationship between atopy and airway responsiveness. In: Sluiter HJ, Van der Lende R, eds. Bronchitis IV. Assen: Van Gorcum, 1988:22-32. 


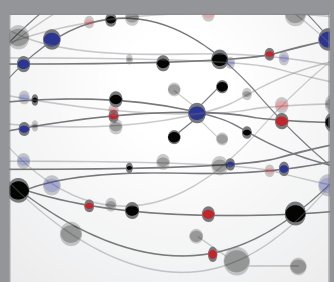

The Scientific World Journal
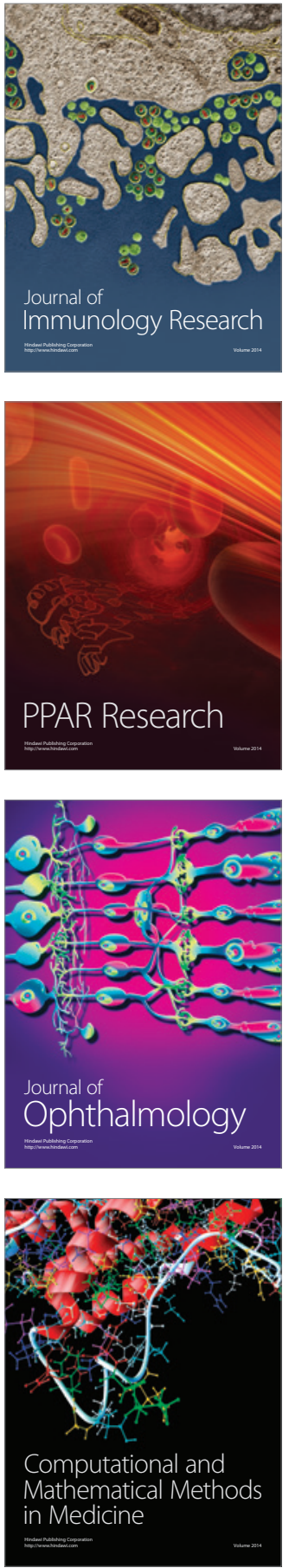

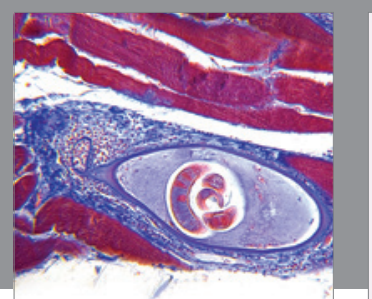

Gastroenterology Research and Practice

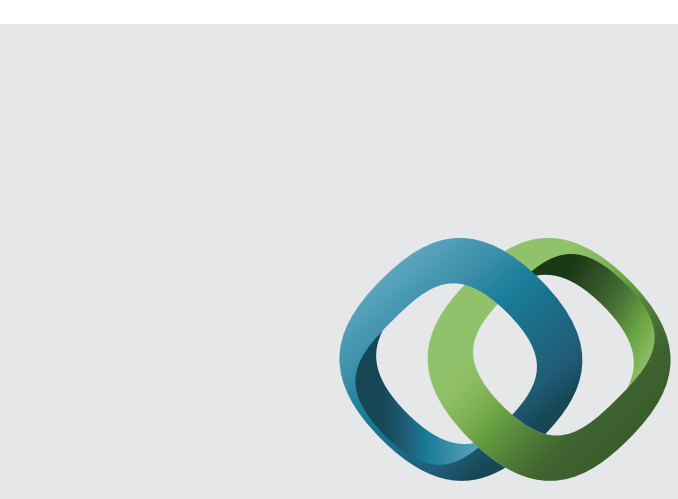

\section{Hindawi}

Submit your manuscripts at

http://www.hindawi.com
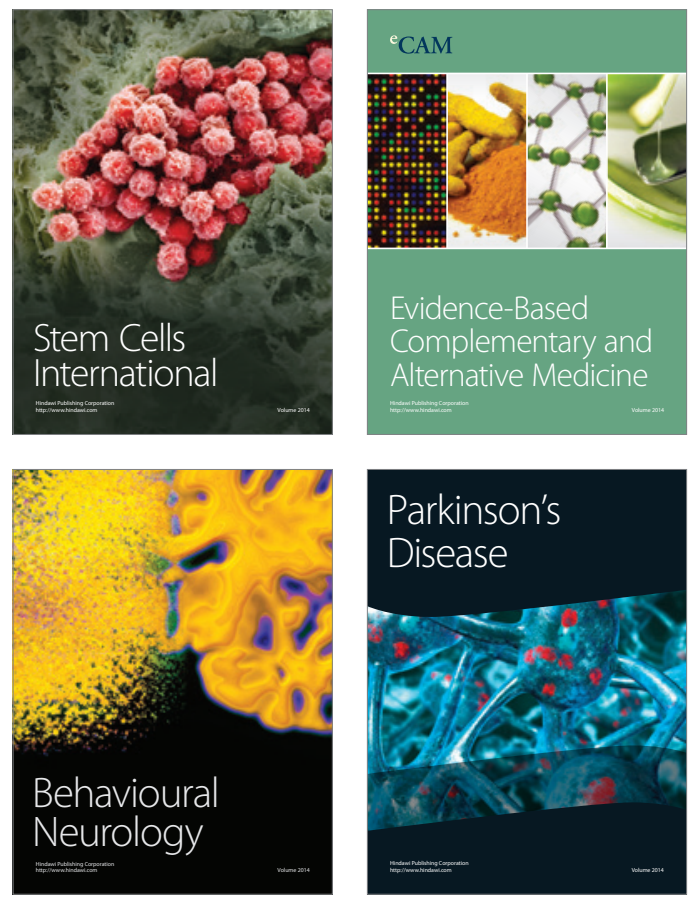
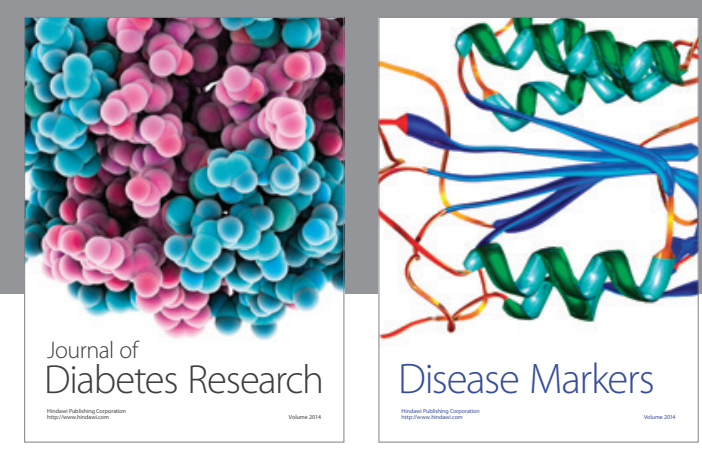

Disease Markers
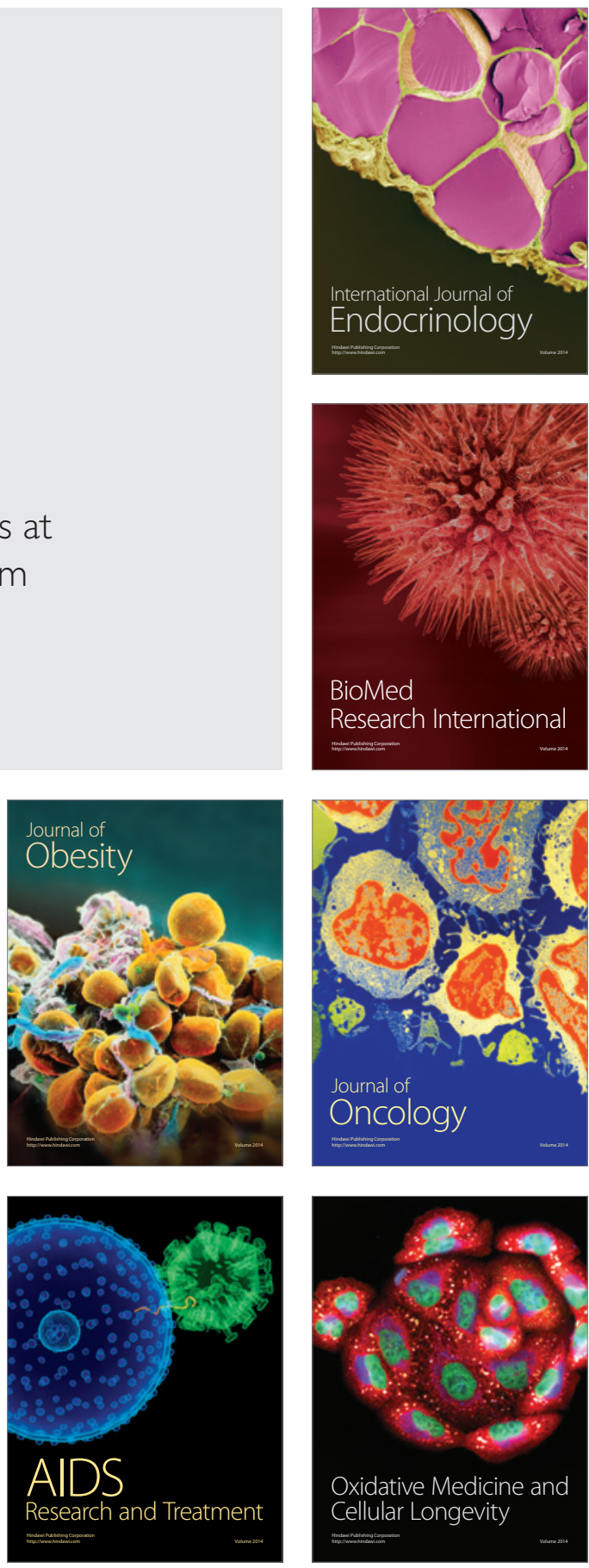